\title{
V4: A Political Tool for Advancing State Interest ${ }^{2}$
}

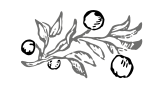

\section{Summary}

The purpose of this paper is to promote thinking on the nature of the relationship between the Visegrad States (the Czech Republic, Hungary, Poland and Slovakia) and to comprehend the circumstances, interests and motivations of the inter-state political alliances in Central Eastern Europe ("CEE"). The Visegrad Group is a regional political platform without a genuine institutional base. This paper seeks to identify the reason for the absence of an intention on the part of the Visegrad States to broaden, deepen or institutionalize their inter-state cooperation. Perhaps, these countries prefer not to force the harmonization of their political actions if their interests do not necessarily meet. A closer look at the FDI inflows reported by these states and at the CEE regional development cooperation possibilities, and a theoretical overview of intergovernmental cooperation in practice can help reveal how easily countries with similar geopolitical and economic positions may achieve common goals (as they understand each other's problems better). Such countries, however, may also become competitors in specific fields. The V4 states cooperate multilaterally so long as the synchronization of their political moves generates roughly equal benefits for each. V4 may be interpreted as a political tool for advancing the political interests of its member states and not as a compulsory or permanent negotiating forum.

Journal of Economic Literature (JEL) codes: F15, F21, F50, F53, O18, O19, Y10, Y91 Keywords: V4, Central and Eastern Europe, intergovernmental cooperation, multilateral diplomacy, state interest, FDI inflow, structural realism, institutional liberalism

BÁlint L. Tóth, PhD student, Corvinus University of Budapest, international relations expert at the Hungarian State Railways (MÁV) (btoth.ir@gmail.com). 


\section{Centripetal political forges among CEE countries}

For the first time after the regime change, the Heads of the Republic of Hungary, the Czech and Slovak Federal Republic and the Republic of Poland met in May 1990 to elaborate a new economic and political framework for an intergovernmental foreign policy partnership following the dismantling of the Council for Mutual Economic Assistance (CMEA) and the Warsaw Pact. For the first time after long decades of soviet repression, the independent CEE governments entered into negotiations with one another without any external pressure. The representatives of the three governments agreed in a joint approach to the western international institutions at the Visegrad Summit of February 1991. That consensus served as a platform and a basis of their future and desired Euro-Atlantic integration. The Visegrad Countries started to develop a system of mutual political interactions in order to evidence their readiness to integrate in advanced international institutions like the European Communities or NATO (Bársony, 1998).

Despite minor discrepancies in attitudes and perceptions, the states of the region moved in the same political direction (accession to the EU, NATO, EBRD etc.) after the 1991 Visegrad Summit: they were interested in a proactive foreign policy and in advancing regional security in order to fill the vacuum left by the dissolution of the Warsaw Pact. After the removal of the Iron Curtain, the Visegrad States became the front-line applicants for accession to the European Community, and very similar institutional and structural reforms took place throughout the region (Péter, 2012:25). These four states adopted the transnational economic system simultaneously. The V4 countries have similar historical, cultural, economic, political and military-strategic backgrounds, enabling them to use their comparative advantage of better understanding each other's problems in international decision-making procedures. It can also be presumed that an increased interdependence reduces the chance of V4 states engaging in conflict (Jackson-Sorensen, 2007:103-104). These similarities allow the observer to see the V4 as a genuine group of countries.

Since the very beginning, the principal challenge for all Visegrad States has been trying to turn their relations, despite their traditionally different foreign policies, into a common strength. ${ }^{3}$ The Visegrad Countries might feel compelled to find common grounds in specific EU-related issues. Until March 2017, when the Council of the EU voted on proposals by the Commission or the High Representative for Foreign Affairs and Security Policy, 352 votes had been assigned to the member states, each with a certain number of votes weighted to reflect the size of their respective populations. As a result, in the aggregate, the Visegrad States had the same number of votes (58) as France and Germany combined (European Council \& Council of the European Union, 2017). Thus, the Visegrad Four had a realistic chance of shaping Europe's decision-making if the governments of all the four countries acted proactively and jointly (see Figure 1).

From November 2014, however, a new procedure for qualified majority voting, also known as the "double majority" rule, is used in the Council. In practice it means that 55 per cent of member states have to vote in favour and the proposal has to be supported by member states representing at least 65 per cent of the total population 
Figure 1: Qualified majority weighting prior to March 2017

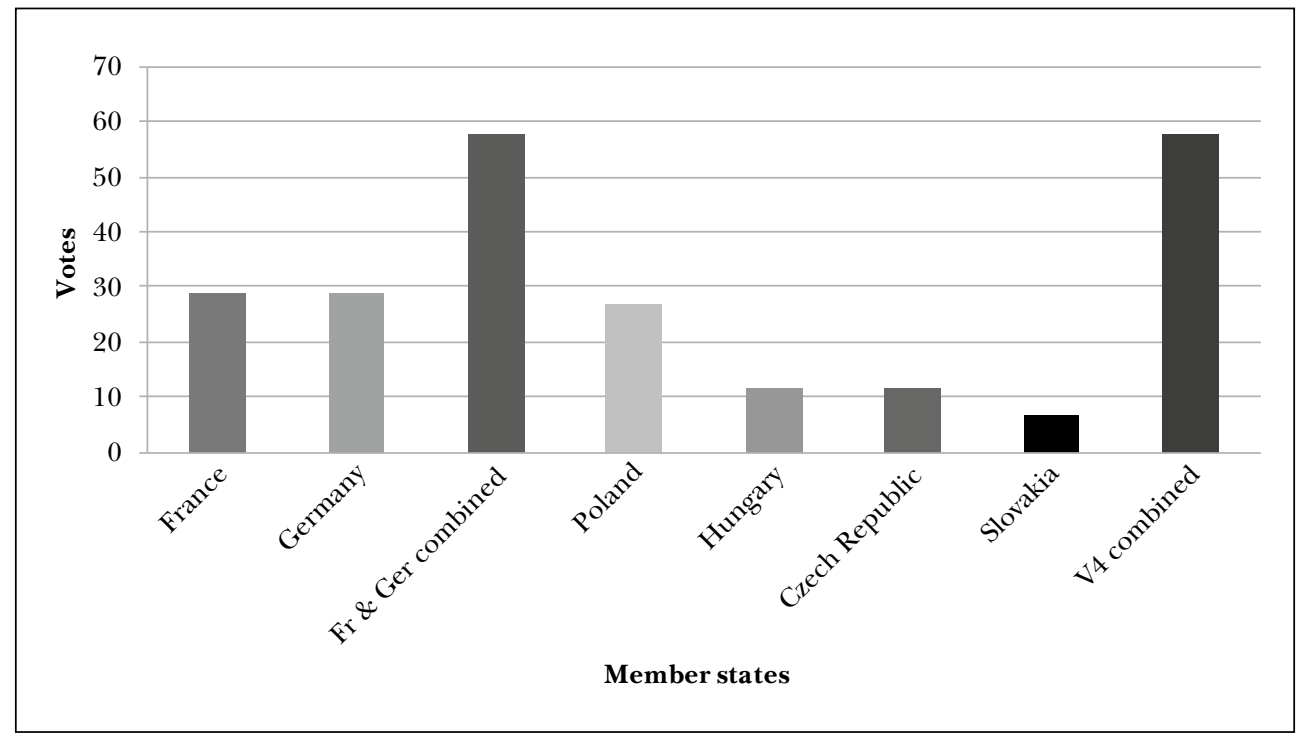

Source: Edited by the author based on EC, 2017

Figure 2: Population of V4 countries (2017)

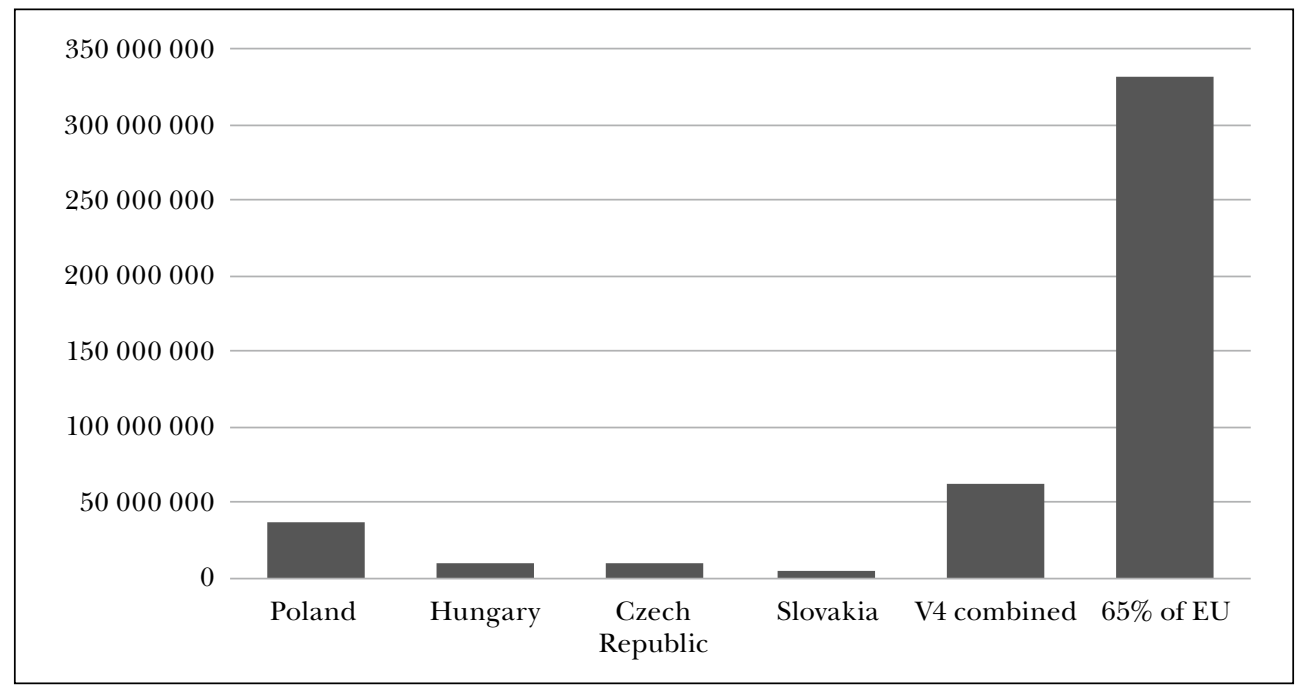

Source: Edited by the author based on Eurostat, 2017

of the EU. The former criterion is beneficial for small-sized member states, while the latter favours larger ones. Consequently, the V4 countries did not benefit from the changes: they include two medium-sized (the Czech Republic and Hungary), one larger (Poland) and one small (Slovakia) country. 
The four CEE states need to find allies in the Community to be able to enforce their interests related to Commission proposals and foreign affairs. As of now, 65 per cent of the total EU population represents 332,673,310 people (2017 estimate). ${ }^{4}$ This figure is more than five times higher than the estimated total population of the Visegrad States $(63,784,690)$. Thus, the V4+ formula (the usual V4 countries plus Slovenia and/or Croatia, Austria) to support CEE interests in the EU institutions is more than crucial. The accession of the countries in the Western Balkans to the EU would be an indisputable advantage for the Visegrad Four group. The political interests of Central Europe (regional military and energy security, infrastructure development etc.) in many cases coincide with the ones of their south-eastern neighbours. A joint action would certainly multiply the decision-making power of smaller EU member states (Tóth, 2017a:8-10). In addition, in order to strengthen their macroeconomic competitiveness, the Visegrad Countries aim at implementing harmonized modernization policies with the best possible utilization of EU cohesion funds. This, again, is a field where their individual interests coincide, so they can achieve absolute gains in concert (Tóth, 2017a:6). Other fields of intergovernmental cooperation within the V4 region are: food safety and quality issues, migration crises and the related EU policies (although their positions do not necessarily coincide), Schengen policies, EU-Caucasus bilateral relations, cultural and educational, research and development projects etc. (Tóth, 2017b).

Support to the EU and NATO enlargements in the Western Balkans region has been one of the top priorities of the Visegrad Group. There are several examples of practical, political and economic assistance (twinning programs, interregional initiatives, EU Member States Consortia, Stabilization and Association Process tools, Western Balkans Fund, NATO's “Open-Doors” policy etc.) provided by the V4 states, both individually and collectively, to Post-Yugoslav countries and to Albania in order to facilitate the accession process (Visegradgroup.eu, 2014). Central European countries strive to increase their "soft diplomacy" activities in the Western Balkan region through the International Visegrad Fund ("IVF", Ministry of Foreign Affairs and Trade, 2017). The Visegrad Countries can offer their expertise in deepening cross-border cooperation with future EU member states.

The Visegrad formula, through its successful security-related and economic integration, has become a model followed by the countries that recently joined NATO and the EU (Bútora, 2011). The European integration of the Western Balkan region is still under way, and one of the major preconditions for accession is the establishment of stable regional partnerships. Western Balkans states might need to adopt a "Visegradstyle" multilateral negotiating forum for a non-compulsory and non-permanent intergovernmental dialogue. The effectiveness of a regional political cooperation does not necessarily depend on the depth of institutional structures. The outcomes of such partnerships could be the results of mere cost-effectiveness analyses.

It is presumed that the historical east-west axis in CEE geopolitics can only be altered by closer ties with the Balkans. Given their predetermined geopolitical situation, bargaining position, economical weight and socio-political experiences, a genuine 
(non-EU and non-NATO) V4 approach to the Western Balkans may serve as one of the few chances for these states to act deliberately in a non-predetermined way in the European arena. To this end, Budapest, Bratislava, Prague and Warsaw make efforts at harmonizing their political actions. Since 2009 each high-ranking Visegrad Four summit has addressed Western Balkans-related questions and V4-Western Balkans foreign ministerial meetings have been organized on an annual basis ever since (Tóth, 2015:25-28).

\section{Case study 1: Regional development cooperation - The Via Carpathia initiative}

The efficiency of a regional development cooperation depends primarily on the complexity of socio-economic processes and the harmony of different development factors. Hence it is crucial to integrate national and subnational levels connecting different areas (economic and financial, geographical, scientific and technical, moral and historical, natural, social, infrastructure, legal and institutional, political, and strategic; Baranyi, 2013). The Europeanization of non-EU member states has been a key factor in regional political partnerships in the CEE area and the related activities have strengthened cohesion between member and candidate states. Moreover, Europeanization may help create a regional identity. A collective regional inter-state decision-making can be perceived also as an opportunity to overcome transnational challenges, to boost the economy in marginalized sectors, to build up efficient infrastructures across state borders and to bring people from different countries together (Centre for Democracy Studies, 2015).

The improvement of transport infrastructure is one of the most significant conditions for sustainable development. Mainly due to the expansion of bilateral trade between Germany and the V4 countries since 1990, supply chains have primarily been formed on the east-west axis in this region. There have been initiatives to create supply chains along the north-south axis too, but so far there is no genuine north-south traffic corridor in the Eastern part of the EU (Lønsetteig, 2017).

Via Carpathia is a planned European north-south transborder transport route running along the eastern border of the EU, connecting Lithuania, Poland, Slovakia, Hungary, Romania, Bulgaria and Greece. The construction of the trail was originally initiated by the Polish government (China-CEEC, 2016). Via Carpathia would cross the west-east corridors leading from Western Europe to Russia and Central Asia and link the Black Sea ports with the TRACECA trail (Europe, the Caucasus and Asia). ${ }^{5}$ One of its major advantages is that it would connect the Eastern and less developed economic areas of Poland, Slovakia and Hungary. The project aims at improving communication and transportation of goods between the Baltic and the Aegean Seas (Centre for Transport Strategies, 2016); stimulating and accelerating economic growth in less developed regions of the countries involved; breaking down logistics obstacles; providing impetus for the free movement of persons, goods, and services; fostering cross-border cooperation and opening up new supply chains; supporting the development of local SMEs; boosting trade in the fast-moving consumer goods; 
as well as supporting tourism industry in the region. A higher level of connectivity increases standards of living as it impedes the movement of workforce from the region, supports the creation of new workplaces and it attracts new investments (Nagy, 2016).

In October 2006 representatives of Lithuania, Poland, Slovakia and Hungary met at the "One Way - Four Countries" intergovernmental conference in Łańcut, Poland to discuss the demand for an integrated, sustainable and efficient transport infrastructure that would provide connectivity to the Carpathian, the Baltic, as well as the Danube macro-regions. In October 2010 Bulgaria, Romania and Greece also joined the initiative. In 2016 the parties signed the second Łańcut Declaration on the extension of the Trans-European Transport Network (TEN-T) by establishing the shortest highway route on the North-South axis connecting Lithuania, Poland, Slovakia and Hungary (The Łańcut Declaration, 2016). ${ }^{6}$

\section{CENTRIFUGAL FORGES}

Once the Visegrad Forum does not prove to be effective enough anymore, the governments involved opt for using other intergovernmental political means to achieve their goals (Slavkov and Weimar triangles, CEFTA, CEI, Salzburg Forum, EU Danube Region Initiative etc.). This shift to other international diplomatic fora, however, does not mean these governments wish to quit the Visegrad formula in other fields of their cooperation. These states do not ignore the former V4 achievements when their governments decide that a specific international political issue is not to be approached through the Visegrad formula.

After the fall of communism there was a significant military and economic security vacuum in CEE and the intention of these countries to join the Euro-Atlantic international organizations as soon as possible was the main driving force behind the partnership of Bratislava, Budapest, Prague and Warsaw (Światłowski, 2015). These governments, however, have always had slightly different political rationales in prioritizing different strategic objectives.

Not many years after the foundation of the Visegrad platform, the initial enthusiasm for cooperation started to slowly disappear, and particular approaches were born. The CEE countries' desire to join the European integration ahead of others had a sort of disruptive effect that fostered rivalry as opposed to pursuing synergies within the region. When one wants to understand the centrifugal forces in the V4 region after the down of the Cold War, the so called "Four fears of the CEE states" have to be taken into consideration (the order is indifferent):

1. To become a buffer zone between the NATO and Russia

2. To turn to an alternative to the European integration instead of being a means of reaching the desired accession

3. The burden of less developed partner states as an obstacle to the Euro-Atlantic integration

4. To put limits to the liberty of foreign policy-making shortly after regaining sovereignty (Lengyel, 2006:162). 
The Czech foreign policy has always been focusing on Germany. As the country does not border with any of the post-Soviet or post-Yugoslav states, it has different geopolitical ambitions and interests then the rest of the V4 states. Prague's diplomacy has always been driven by pragmatism, cost-effectiveness, and particular ideologies (e.g. the Czech opt-out policies related to certain EU regulations). Poland has close relations with Ukraine, Belarus and Lithuania, as these territories represent former parts and current neighbours of the country. Prague's political activity was primarily focusing on identifying individual ways of the Euro-Atlantic integration and supplying development assistance to the Western Balkans region, while the unique position of Poland, Hungary and Slovakia determined their eastern orientation. The Czech Republic, Hungary, and Slovakia have consciously followed pendulum politics between Western Europe (Germany) and Russia, while Poland still gives a great emphasis to protection from Russian influence in Eastern Europe. And, of course, the geopolitical foci of each individual V4 country have constantly changed from time to time according to the changes in their governments, as different leaderships have prioritized different key issues.

On the other hand, these states have been in competition with one another for Western financial and security aids and resources (Bársony, 1998). This was, however, nothing new under the sun. Before the 1990 regime change, economic relations within the region had been nothing but a forced interdependent harmonious system of Moscow's satellite states (CMEA), where the individual bilateral connections to the Soviet Union had always been more significant than the multilateral relations with one another (Newnham, 2002:144). So the Visegrad Countries were made competitors in certain economic sectors (steel production, agriculture; Bársony, 1998).

\section{Case study 2: Foreign investments}

The shift of the Visegrad Four countries from state-controlled economies towards market competition can be seen as a considerable policy paradigm change, which not only altered the economic policy goals and means but also revised the values and beliefs that characterized the Central European way of thinking prior to the regime change in 1990 (Drahokoupil, 2009:57). In order to help develop their industrial bases, the Visegrad Countries tried to attract as much foreign direct investments as possible. V4 governments have been in constant competition for equity capital, reinvested earnings and other capital originating from other, mostly Western countries (Drahokoupil, 2009:23-31). Investors were initially attracted by the relative institutional advantages of the Visegrad region (new liberal regulations, exploitable cheap and skilful workforce, capital attraction policies, numerous unexploited market opportunities etc.).

In 2016 Prague reported USD 115,204 million FDI stock, which represented 59.7 per cent of the country's annual GDP. For the same period Budapest calculated USD 77,721 million FDI stock, equal to 61.8 per cent of the GDP. In Poland the figure was USD 185,903 million in 2016 representing the 39.8 per cent of the respective 
gross domestic product. Bratislava recorded an FDI stock of USD 41,615 million for 2016 giving the 46.5 per cent of the country's GDP. The figures inserted below show us a three-year tendency dated from 2015 to $2017 .^{7}$

Figure 3: FDI stock in USD (2015-2017)

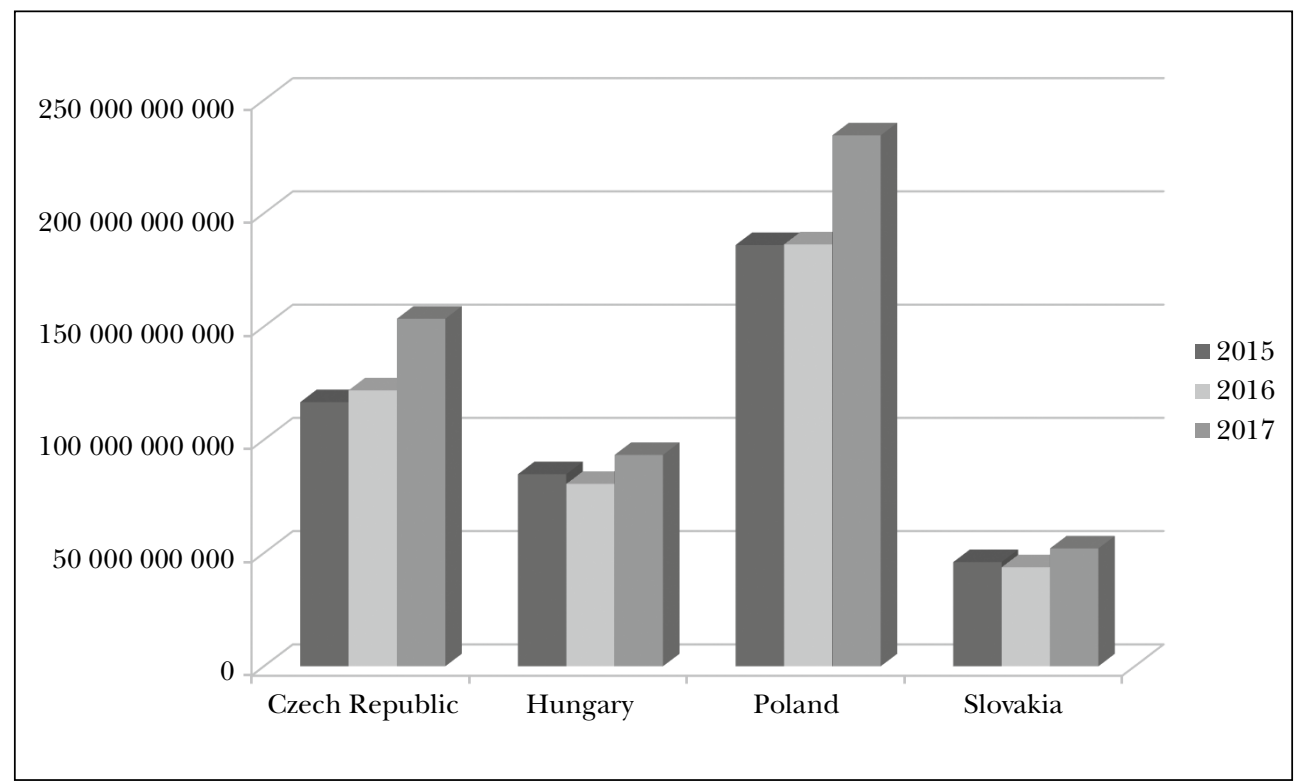

Source: Edited by the author

Figure 4: FDI stock in per cent of GDP (2015-2016)

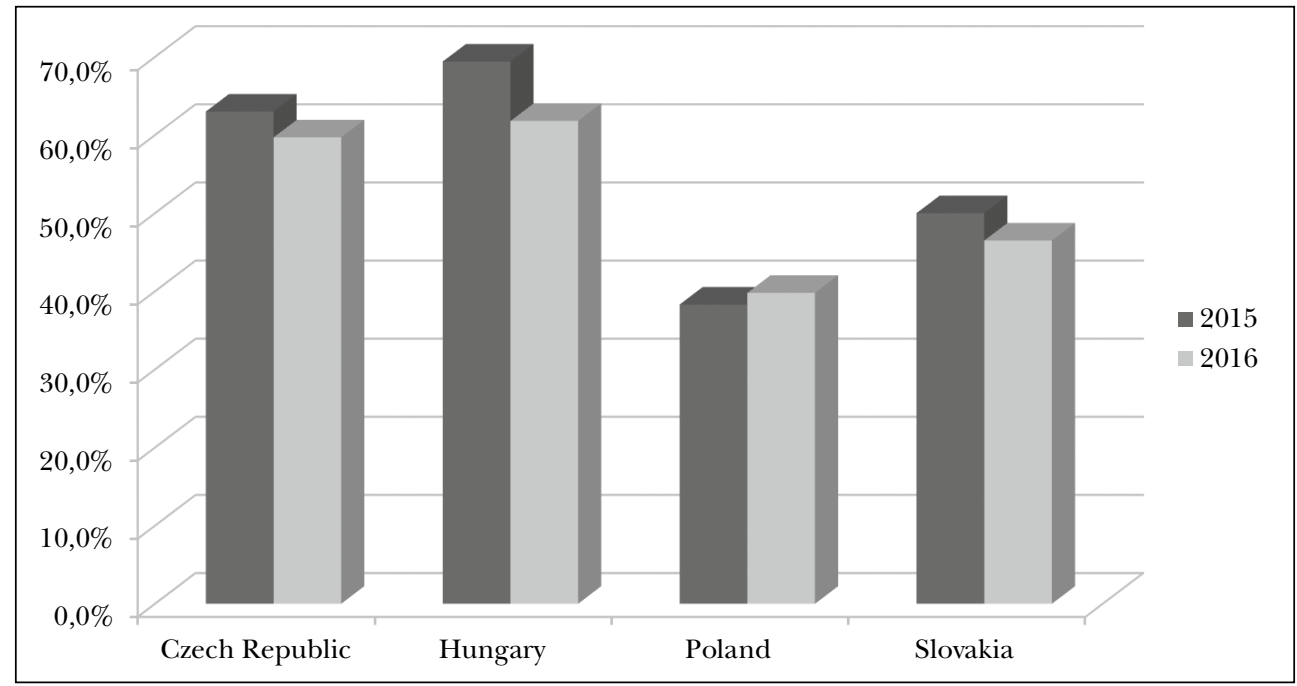

Source: Edited by the author 
As the V4 Countries' heavy reliance on foreign capital inflows has made them competitors in the European market they have never harmonized their policies in the field of FDI attraction. Each V4 states have developed strategies principally driven by industrial growth that followed transnational trends and policies. In this latter process international institutions have played a considerable role (Drahokoupil, 2009:55). For a better understanding of the centripetal and centrifugal forces among V4 states, below is the theoretical background of these four countries' supranational intergovernmental political cooperation.

\section{A THEORETICAL POINT OF VIEW}

In a long-term perspective, any inter-state cooperation be effective if the states involved choose their partners carefully and do not force the harmonization of political actions where their interests do not necessarily meet. Multilateral partnership within international political platforms is considered as a main vehicle for advancing the key foreign policy interests of states with relatively weak decision-making positions (such as CEE countries) on a global scale. A harmonized cooperation along shared interests can be used in a "smart" way to compensate for small size and the absence of powerful means of pursuing international policies, thus allowing small states to punch above their real weights. The interest endorsement system of international organizations (such as the EU) forces states with relatively modest political weight to form alliances with other less powerful countries that are also in weak positions in comparison to larger powers that can exert higher influence in global or continental policy-making. The ability of states with relatively weak political positions to shape the political agenda at supranational levels may thus be strengthened and these governments may gain comparative advantages by harmonizing their actions. ${ }^{8}$

According to structural realists, the basic factor in the structure of an international system is the division of power and not the common goals, shared interests, mutual dependence and similar positions of the cooperating states (Waltz, 1979:17-30). Neoliberal institutionalism assumes that states focus primarily on their absolute gains, and emphasizes the prospects for cooperation, while structural realism supposes that states are largely concerned with relative gains and points out the prospects for conflict. The followers of the latter school think that the more states care about relative gains, the more a gain for one state tends to be seen as a loss by others and the more difficult cooperation will be (Powell, 1991:1). This statement is underpinned by the fact that Visegrad Countries have been competitors in attracting foreign investment, as discussed above. ${ }^{9}$

During the first 25 years, the V4 platform did not intend to integrate other CEE states in the coalition, nor did they want to extend the synergies beyond the most obvious common goals of the governments involved. States cooperate multilaterally as long as the synchronization of their political movements generates relatively equal profits for each (Caporaso, 1992:8-9). During their accession to the European Union the Visegrad Countries proved to be unable to agree on a joint negotiating position and to assume the leadership of a bloc of candidates that would be a natural centre of gravity (Žantovský, 2006). 


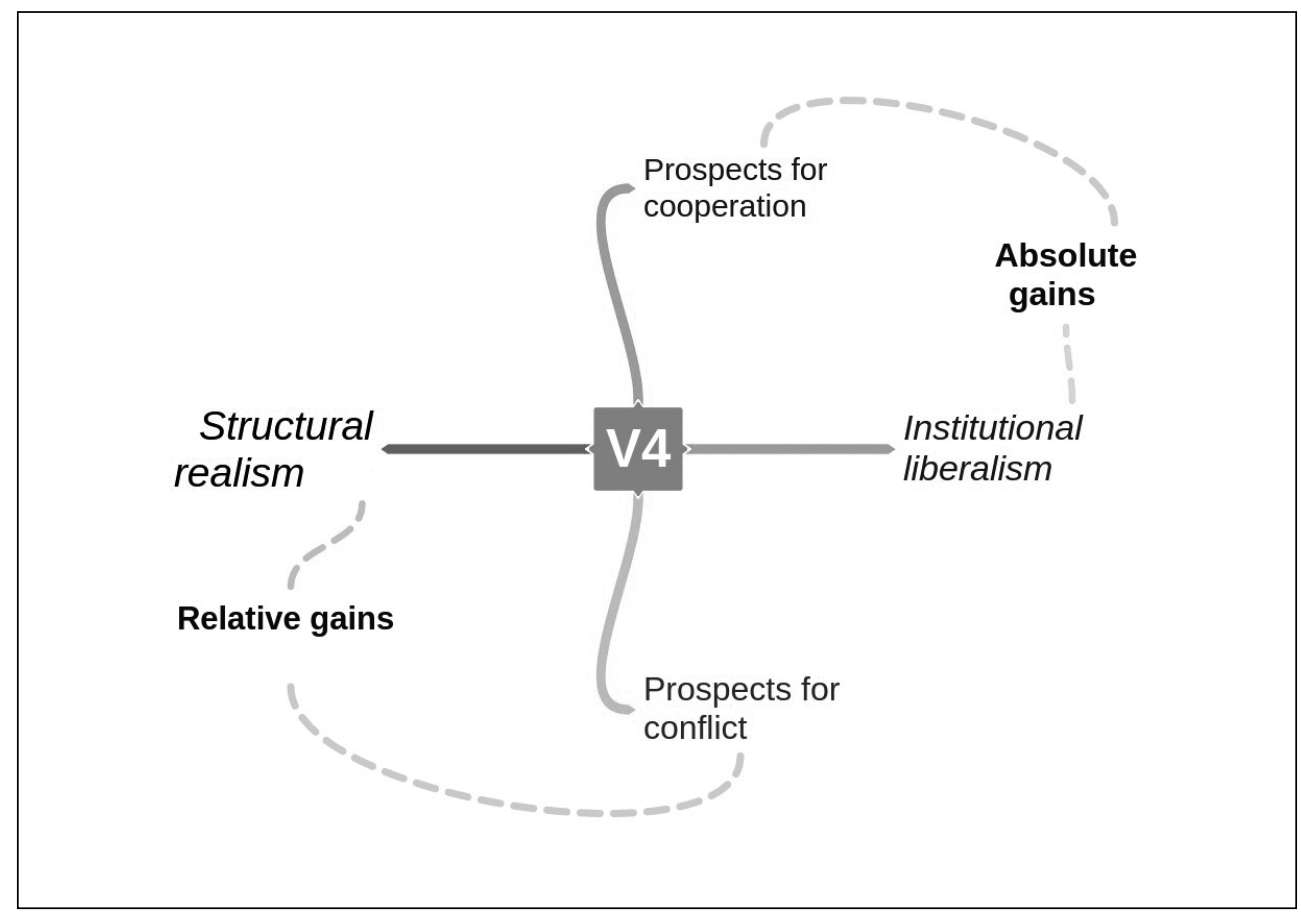

Source: Edited by the author

\section{CONGLUSION}

The V4 Countries are looking for points of convergence, possibilities to reconcile and express their respective individual positions in order to formulate a joint one. The Visegrad Group has not become a compulsory negotiating forum, nor has it grown to be a well-institutionalized international organization either. The slightly different geopolitical determinations and the constant competition for foreign investors have been some of the major factors that prevented the V4 Countries from finding the attributes necessary for a predominant regional political entity (a better institutionalized cooperation, more willingness to compromise etc.). Institutional neoliberalism says that a higher level of transnational relations between countries once occurred cannot be ignored anymore. The accession of the Visegrad Countries to NATO and the EU required increased government interactions between Poles, Czechs, Hungarians and Slovaks, however, the competition and discrepancies in geopolitical aims prevented them from finding appropriate ways to handle existing conflicts and tensions. Nevertheless, by its successful security and economic integration Visegrad has become a good example, a model that was followed by the other candidates to join NATO and the EU. 


\section{Bálint L. Tóth: V4: A Political Tool for Advancing State Interest}

\section{Notes}

1 The thoughts and views set out in this study constitute the author's opinion and do not necessarily reflect the official view of the Hungarian State Railways or the Corvinus University of Budapest.

2 Acknowledgements to Professor István TÓZSA (National University of Public Service) for his valuable advice. All the graphs and diagrams in this text were created and designed by the author.

3 During foreign policy crises, Hungary has traditionally looked to Germany, the Czechs and Slovaks to Russia, and Poland to France, the United Kingdom or the United States (Čarnogurský, 2006).

4 EUROSTAT: Population 2017, ec.europa.eu/eurostat/tgm/table.do?tab=table\&language $=$ en $\& p c o d e=t-$ ps00001\&tableSelection=1\&footnotes=yes\&labeling=labels\&plugin $=1$.

5 TRACECA is an internationally recognized program aimed at strengthening the economic relations, trade and transport communication in the regions of the Black Sea basin, South Caucasus and Central Asia. (TRACECA, 2017)

6 Via Carpathia includes prospects currently under discussion for the construction of branches to neighboring countries like Belarus, Ukraine, Turkey, Macedonia, Albania (Centre for Transport Strategies, 2016)

7 Santander Trade Portal, Foreign Investment. Czech Republic: https://en.portal.santandertrade.com/ establish-overseas/czech-republic/foreign-investment, Hungary: https://en.portal.santandertrade. com/establish-overseas/hungary/foreign-investment, Poland: https://en.portal.santandertrade.com/ establish-overseas/poland/foreign-investment, Slovakia: https://en.portal.santandertrade.com/establish-overseas/slovakia/investing.

8 Hence it can be asserted that states in relatively weak political positions have to cooperate more actively than the larger powers within international organizations where the outcomes are products of interactions between actor preferences and institutional rules.

9 Competition, however, is inherent in the European integration and contributes to the development of CEE market economies which may be considered as an absolute gain for all V4 countries (Balogová, 2008).

\section{REFERENGES}

Balogová, Beata (2008): V4 Stands Together to Attract Investors. The Slovak Spectator, Vol. 14, No. 6, visegradgroup.eu/about/v4-stands-together-to (accessed 22 December, 2017).

Baranyi Béla (2013): Integrated Regional Development (Theoretical Textbook). [University of Debrecen, Centre for Agricultural and Applied Economic Sciences, Debrecen. www.tankonyvtar.hu/hu/tartalom/ tamop412A/2011-0029_de_integrated_regional_development_theoretical/ch01s03.html (accessed 22 December, 2017).

Bársony, András (Rapporteur) (1998): For Debate in the Standing Committee see Rule 47. CEFTA Parliamentary Assembly Committee on Economic Affairs and Development, http://assembly.coe.int/nw/xml/XRef/ X2H-Xref-ViewHTML.asp?FileID=8368\&lang=en (accessed 22 December, 2017).

Bútora, Martin (2011): A Miracle Called Visegrad. Visegradgroup.eu, visegradgroup.eu/the-visegrad-book/ butora-martin-miracle (accessed 22 December, 2017).

Caporaso, James A. (1992): International Relations Theory and Multilateralism: The Search for Foundations. International Organization, Vol. 46, No. 3.

Čarnogurský, Ján (2006): Visegrad Yesterday, Today and Tomorrow. In: Michnik, Adam (ed.): The Visegrad Group a Central European Constellation. Publication on the Occasion of the 15th Anniversary of the Visegrad Group. International Visegrad Fund, Bratislava, 33-35. (accessed 22 December, 2017)

Centre for Democracy Studies (2015) and Andrássy Forum for Western Balkan Studies. Conference paper, Andrássy University, Budapest.

Centre for Transport Strategies (2016): Via Carpathia Pan-European Highway to Branch to Ukraine. 16 March, en.cfts.org.ua/news/via_carpathia_pan_european_highway_to_branch_to_ukraine (accessed 22 December, 2017). 


\section{Polgári Szemle · 14. évfolyam 1-3. szám}

Cooperation Between China and Central and Eastern European Countries (2016): Via Carpathia Transport Corridor of Strategic Importance for CEE: Polish PM. 10 November, www.china-ceec.org/eng/zdogjhz_1/ t1414331.htm (accessed 22 December, 2017).

Drahokoupil, Jan (2009): Globalization and the State in Central and Eastern Europe. The Politics of Foreign Direct Investment. Routledge, Oxon (accessed 22 December, 2017).

EC (2017): Qualified majority. European Council, consilium.europa.eu/en/templates/content.aspx?id=1305.

Eurostat (2017): Population 2017. http://ec.europa.eu/eurostat/tgm/table.do?tab=table\&language $=$ en $\&$ pcode $=$ tps $00001 \&$ tableSelection $=1 \&$ footnotes=yes\&labeling=labels\&plugin=1 (accessed 22 December, 2017).

Jackson, Robert - Sorensen, George (2007): Introduction to International Relations: Theories and Approaches. Oxford University Press, Oxford.

The Łańcut Declaration (2016) of the Ministers of Transport Hungary, the Republic of Lithuania, the Republic of Poland, Romania, the Slovak Republic, the Republic of Turkey and Ukraine on Strengthening the Cooperation in the Area of Transport in the Carpathians and Continuation of the Via Carpatia Development. mib.gov.pl/files/0/1796967/deklaracjalancucka.pdf.

Lengyel László (2006): Illeszkedés vagy kiválás. Osiris Kiadó, Budapest.

Lønsetteig, Aleya Begum (2017): Poland and Ukraine to build Via Carpatia. Global Trade Review, 25 October, gtreview.com/news/europe/poland-and-ukraine-to-build-via-carpatia/ (accessed 18 December, 2017).

Ministry of Foreign Affairs and Trade (2017): Hungary's V4 Presidency Pays Particular Attention to Supporting Western Balkans. Ministry of Foreign Affairs and Trade, 20 September, v4.gov.hu/hungary-s-v4-presidency-pays-particular-attention-to-supporting-western-balkans (accessed 22 December, 2017).

Nagy László Nándor (2016): Utak a sikerhez. Heti Válasz, 22 October, valasz.hu/uzlet/utak-a-sikerhez-120835 (accessed 22 December, 2017).

Newnham, Randall Everest (2002): Deutsche Mark Diplomacy: Positive Economic Sanctions in German-Russian Relations. Penn State University Press, Pennsylvania.

Péter, László (2012): Hungary’s Long Nineteenth Century. Constitutional and Democratic Traditions in a European Perspective. Collected Studies. Brill, Leiden-Boston.

Powell, Robert (1991): Absolute and Relative Gains in International Relations Theory. American Political Science Review, Vol. 85, No. 4, https://doi.org/10.2307/1963947.

Światłowski, Bartosz (2015): Unity of the Visegrad Group in the Face of War in Ukraine. Visegrad Plus, 12 March, visegradplus.org/opinion/unity-of-the-visegrad-group-in-the-face-of-war-in-ukraine (accessed 22 December, 2017).

Tóth Bálint László (2015): A Visegrádi csoport (V4) Nyugat-Balkán-politikája. Külügyi Szemle, Vol. 14, No. 2, 25-41, kki.hu/assets/upload/Teth.pdf (accessed 22 December, 2017).

Tóth Bálint László (2017a): A Visegrádi Négyek. Állandó szövetség vagy eseti koalíció? Szabolcs-SzatmárBeregi Szemle, Vol. 52, No. 1, 3-20. (accessed 22 December, 2017).

Tóth Bálint László (2017b): V4: költség-haszon elvú törékeny egység az Orbán-kormány kezében. Átlátszó. hu, https://pcblog.atlatszo.hu/2017/03/24/v4-koltseg-haszon-elvu-torekeny-egyseg-az-orban-kormanykezeben/ (accessed 22 December, 2017).

TRACECA (2017): TRACECA Member Countries. traceca-org.org/en/countries (accessed 22 December, 2017).

Visegradgroup.eu (2014): Hungarian Presidency in the Visegrad Group (2013-2014). Visegradgroup.eu, www.visegradgroup.eu/documents/presidency-programs/20132014-hungarian (accessed 22 December, 2017).

Waltz, Kenneth (1979): Theory of International Politics. Waveland Press, Long Grove (accessed 22 December, 2017).

Žantovský, Michael (2006): Visegrad Between the Past and the Future. visegradgroup.eu, visegradgroup.eu/ the-visegrad-book/zantovsky-michael (accessed 22 December, 2017). 